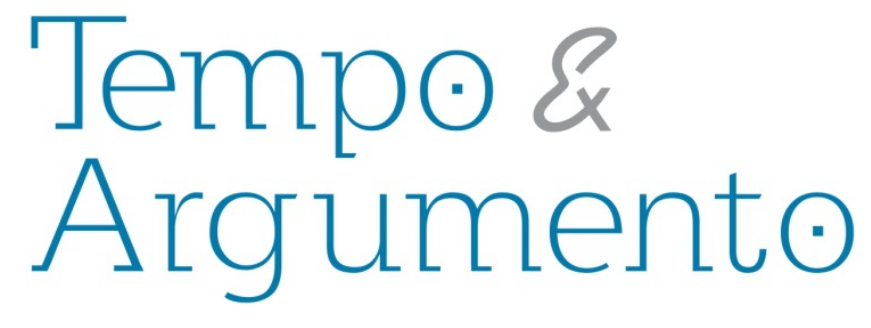

\title{
Tempos de pós-democracia: ausência do povo
}

\section{Céli Regina Jardim Pinto}

Doutorado em Ciência Política na University of Essex - Inglaterra. Professora do Programa de Pós-Graduação em História da Universidade Federal do Rio Grande do Sul (UFRGS).

Porto Alegre, Rio Grande do Sul - BRASIL celirjp@gmail.com

\footnotetext{
Para citar este texto:

PINTO, Céli Regina Jardim. Tempos de pós-democracia: ausência do povo. [Debate]. Revista Tempo e Argumento, Florianópolis, v. 9, n. 21, p. 472 - 481, maio/ago. 2017.
}

DOI: $10.5965 / 2175180309212017472$

http://dx.doi.org/10.5965/2175180309212017472

As primeiras duas décadas do século XXI têm sido palco de crises que se alastram, praticamente, por todo o planeta. Podem ser identificadas três grandes ocorrências: a crise do capitalismo desde 2008; a expansão das guerras no Oriente Médio e na África; a crise política, expressa pelo esgotamento do modelo liberal representativo de democracia. 
Este ensaio tratará da crise política que, em termos muito gerais, se caracteriza: 1. pelo esgotamento de modelos de democracia garantidores dos direitos sociais, com o fim da social democracia europeia, o fracasso do ensaio de Obama nos Estados Unidos e a crise dos governos de inspiração populista na América Latina; 2. pela fragilidade das instituições políticas, como garantidoras do funcionamento do pacto democrático; 3. pela crise no sistema político partidário, quando os partidos perdem seu espaço de enunciadores de discursos políticos capazes de interpelarem a sociedade; 4. pela descrença das populações em geral, principalmente dos jovens, na política institucional; 5. pelo aparecimento de grandes manifestações de rua, desde 2011, no mundo em geral, e de 2013, no Brasil; 6. por uma generalizada associação entre política e corrupção.

A crise, pois, gera - e, ao mesmo tempo, se alimenta dele - um novo pacto de poder, característico das primeiras décadas do século XXI, que se expressa na noção de pós-democracia. Grosso modo, tal noção pode ser caracterizada como: presença do autoritarismo na governança internacional (Ballestrini, 2017); despolitização da vida política, expressa na negação do dissenso e do antagonismo como essencial para o regime democrático (Rancière, 2010); 3. perda de consistência republicana das instituições políticas, em que se incluem os poderes executivo, legislativo e judiciário, e os partidos políticos; 4. surgimento do cidadão despolitizado como modelo, o que Dardot e Laval (2016) chamam de sujeito neoliberal e Brown (2015) de homo oeconomicus.

Aqui não há espaço, nem é o propósito, para discutir cada um dos temas elencados acima. O objetivo é levantar alguns pontos para reflexão a partir do pressuposto de que o sistema democrático, para cumprir os seus essenciais requisitos (igualdade perante a lei, liberdade de informação e garantia de funcionamento de instituições políticas), necessita de uma incerteza política constitutiva que emana das disputas entre grupos partidários, razoavelmente definidos em termos ideológicos e dependentes dos eleitores para chegarem ao poder. Para o sistema funcionar, é preciso que os eleitores tenham, não só informação e todos os seus direitos políticos e civis garantidos, mas também se constituam como sujeitos políticos que se reconhecem no regime democrático. Neste sentido, o desaparecimento deste personagem essencial é o 
efeito mais visível e grave do rompimento do pacto democrático, que deveria envolver o dissenso das ideias antagônicas. A disputa política desaparece e as instituições propriamente políticas, cujos membros são eleitos em pleitos democráticos, perdem espaço e legitimidade para instituições que falam a partir de discursos de autoridade, não passíveis de serem contestados: o saber jurídico; as leis do mercado; o sistema financeiro, representados nos governos nacionais por Ministros da Fazenda, Bancos Centrais e, no nível internacional, pela governança de instituições como FMI e BIRD.

Maquiavel, já no século XVI, em sua famosa obra O Príncipe, chamava a atenção para a necessidade de o príncipe tomar em consideração o povo, os habitantes de seu território. Para ele, sempre era melhor governar com o povo a seu favor, pois tê-lo contra sinalizava um preço muito alto a pagar. Dizia Maquiavel: "Concluo pois que um príncipe não deve temer as conjuras quando tiver o povo a seu favor; porém, caso a população o odeie e seja sua inimiga, haverá motivos para temer tudo e todos" (Maquiavel, 2010 [1516], p. 110).

A democracia moderna, inaugurada com a Guerra de Independência dos Estados Unidos e com a Revolução Francesa, ambas inspiradas pelas ideias iluministas liberais e excepcionalmente democratas, como as de Rousseau, trouxeram para o centro da vida política o cidadão branco, do sexo masculino, dotado de direitos civis e políticos. Olympe de Gouges confrontou a Declaração dos Direitos dos Homens da Revolução Francesa e escreveu, ainda em plena revolução, A Declaração dos Diretos das Mulheres, com a intenção de também incluí-las como cidadãs de direito.

O cidadão como individuo, dotado de razão e poder de decisão, foi visto por Marx como um engodo do pensamento burguês, que pretendia, desta forma, impor a ideia de uma falsa igualdade para assim poder dominar. Desacreditando na democracia, que entendia como um arranjo político burguês, prevê a superação do capitalismo através do acirramento da luta de classes, na qual o proletariado teria o protagonismo. Marx falava da ditadura do proletariado como o último momento da política. E, ao contrário, das experiências revolucionárias nele inspiradas, dava centralidade à participação popular, à política como enfrentamento e ocupação pelo proletariado do Estado. Gramsci (1978), 
talvez o maior filósofo da política dentro do marxismo, falou insistentemente das demandas e tradições populares, da hegemonia que se calcava no reconhecimento, pelo proletariado, dos interesses das demais classes e grupos oprimidos. A própria guerrilha, vitoriosa na revolução cubana, que se estendeu sob o comando de Che Guevara para a América Andina, bem como a sua versão brasileira durante a ditadura cívico-militar, na região do Araguaia, tinha o sonho de arrebatar o apoio popular.

A segunda metade do século XX e as primeiras duas décadas do XXI conheceram a força de um novo sujeito político: o povo. Liberais e marxistas trataram de desqualificá-lo de forma muito semelhante, considerando-o massa de manobra das elites. Mas interpretações mais atuais desconstruíram o preconceito, mostrando que o povo é um sujeito constituído na luta política e não a junção manipulada de um amontoado de pessoas. Sob a designação de populismo ou não, surge então, em diferentes momentos e locais, a poderosa figura do povo: na Argentina de Perón; no Brasil de Vargas; na Venezuela de Chaves, na Bolívia de Evo Morales; na Argentina de Cristina Kirchner; no Brasil de Lula.

Ernesto Laclau (2005) é o principal expoente da perspectiva que dá status teórico à categoria povo, afirmando que ele se estabelece a partir de uma relação antagônica com o poder dominante, no momento em que demandas específicas dos diferentes grupo esmaecem, tornando-se equivalentes. O povo como sujeito político surge deste processo unificado em uma cadeia de equivalências que condensa as diferentes demandas frente ao poder dominante.

Os governos populistas não são antidemocráticos por definição, mas se afastam, em maior ou menor medida, da democracia liberal representativa. Neles, o líder tem uma relação direta com o povo, minimizando algumas vezes as instituições, criando partidos políticos ou transformando-se em representantes incontestes de partidos já existentes. Independente da relação do líder populista com a democracia, ou do próprio populismo com o regime, o importante aqui é reter a ideia de que não há populismo ou líder populista sem a participação popular. 
A partir de 2011, inicia-se a época das grandes manifestações de rua na Espanha, na Grécia, no Chile, em alguns países árabes, como o Egito, a Síria, o lémen e mesmo nos Estados Unidos, em Nova York. Em 2013, esse fenômeno, com características muito próprias, aparece no Brasil e se estende até 2016. Evidentemente, antes de 2011, o mundo conheceu inúmeras manifestações de rua. No Brasil, por exemplo, ficaram marcadas na história as que se sucederam ao suicídio de Getúlio Vargas, em 1954; a Marcha da Família com Deus pela Liberdade, em 1964; a Marcha dos 100 mil, em 1968; as grandes manifestações a favor das Diretas já, em 1983/84.

Entretanto, há uma novidade importante nestas manifestações da segunda década do século XXI: elas não se organizam ao redor de um evento traumático, como um suicídio ou uma ameaça, como o comunismo para parte majoritária dos católicos em 1964, ou contra uma ditadura, em 1968. Também não ocorrem por uma luta específica, como a eleição direta para presidente. Com exceção do caso do Chile, onde as manifestações tinham um foco na luta pela educação pública e gratuita, em todos os outros casos o estopim foi um mal-estar generalizado com a política, os partidos políticos, a corrupção, as políticas de austeridade impostas por organismos internacionais, os regimes autoritários e/ou totalitários, nos casos árabes.

Os resultados destas manifestações foram muito variados. No Chile, um governo de centro-esquerda ganhou as eleições e promoveu reformas, ainda problemáticas, na educação. Na Espanha, das manifestações surgiu um novo partido político, com jovens lideranças e bom desempenho eleitoral, o Podemos. Na Grécia, o crescimento do partido de esquerda, o Syriza, nas eleições de 2012, é considerado consequência das manifestações do ano anterior. Já a chamada Primavera Árabe provocou duas guerras civis de grande violência na Síria e no lémen e, após breve esperança de democratização, um novo regime autoritário e militarista no Egito. Na Líbia, as manifestações evoluíram para uma guerra civil com a intervenção dos Estados Unidos, o assassinato de Al Gaddafi e a destruição do próprio país. Da Primavera Árabe, parece que a única sobrevivente é a Tunísia, que vive uma transição para um regime de carácter mais democrático como efeito das mobilizações, após anos de violência. No Brasil, as manifestações de 2013 
transformaram-se em uma campanha organizada a favor do impeachment da presidenta da república eleita, com contornos ideológicos claramente conservadores e a chancela da maior rede de telecomunicações do país.

As grandes manifestações não construíram novos sujeitos políticos, diferenciados dos tradicionais atores, em crise nas democracias representativas. Na verdade, o que elas revelaram, mais fortemente, foi o distanciamento entre aqueles que estiveram nas ruas e também os que as apoiaram, pelos meios de comunicação ou medias sociais - e a política institucional. O sujeito descrente, desiludido, afastado dos partidos, não se constitui em sujeito político e tende a se relacionar com o mundo público como um ente com interesses eminentemente privados. Isto envolve muito mais do que mudança de perspectivas dos entes privados, traz consequências concretas para a vida política, para a formulação de interesses coletivos e para o futuro da democracia.

Três eventos políticos, ocorridos em diferentes países, nos últimos dois anos, são reveladores da despolitização em curso, já expressa nas manifestações e que é, em grande medida, definidora do cenário de pós-democracia.

O primeiro evento é o referendo sobre a saída do Reino Unido da Comunidade Europeia, acontecido em 2016, conhecido como Brexit. O anti-europeísmo era muito forte entre parte dos membros do Partido Conservador inglês e do Partido Independente, que pressionavam o então Primeiro Ministro David Cameron para se afastar da Comunidade. Em que pese a sempre difícil relação do Reino Unido com a Europa, inclusive não adotando a moeda comum, Cameron apostava que o referendo garantiria a permanência na Comunidade, já que esta era a vontade do Partido Trabalhista e de parte dos conservadores. Mas os eleitores votaram pela saída e, paradoxalmente, quando a vitória se anunciou, o sentimento foi de derrota. Disseram que não votariam pela saída nas pesquisas, mas fizeram um voto de protesto, porque estavam receosos com a onda imigratória. Na verdade, cada um que votou a favor apostou que o outro votaria contra. Um ano depois, a primeira ministra Tereza May, contando antecipadamente com os votos dos eleitores que apoiaram a saída do país da CE, antecipou as eleições gerais para tornar seu governo ainda mais forte. Mas os mesmos eleitores, surpreendentemente, fizeram o 
partido trabalhista renascer, mesmo com um líder considerado à esquerda da maioria do próprio partido.

Também em 2016, nenhum instituto de pesquisa indicou que Donald Trump se tornaria presidente dos Estados Unidos. Sua candidatura começou quase como um escracho, os próprios republicanos não acreditavam nela. A vitória de Hillary Clinton era óbvia para Trump, para a grande mídia do país e para a candidata, mas o resultado das urnas deixou o país petrificado frente à vitória do magnata. Por que Trump ganhou? São muitas as explicações, mas gostaria de me deter em duas: a primeira refere-se ao seu eleitor preferencial: homens brancos de classe operária, desempregados ou desalojados de seus empregos industriais. Este é um fenômeno particularmente interessante no capitalismo globalizado do século XXI. Estamos frente ao proletariado de cartilha, mas que foi desalojado da fábrica e se tornou um conservador, mais do que isto, um reacionário, capaz de votar em sua própria negação, no representante mais explicitamente declarado da burguesia. A segunda refere-se ao fato de Hillary Clinton representar a política estadunidense por excelência, pertencer à elite do Partido Democrata e fazer parte de um clã político. Trump era o outsider, o homem celebridade de televisão, milionário e excêntrico, que não respeitava as regras da política, nem o savoir faire do jogo político das eleições presidenciais dos Estados Unidos. Seu eleitor não pertence a nenhuma das categorias de sujeito político, é o despolitizado na política.

O terceiro exemplo, já em 2017, é a eleição de Emannuel Macron na França, um homem de 39 anos, sem nenhuma experiência política eleitoral, que abandonou o governo de François Hollande e fundou um partido, não por acaso com as iniciais de seu nome: En Marche. Ele obteve uma vitória arrasadora nas eleições presidenciais, confirmada nas eleições legislativas posteriores, fato que tornou o En Marche quase um partido único. Macron foi efeito do desgaste do sistema partidário francês. A alternância entre a direita e uma esquerda desfigurada deixou um flanco aberto para a negação dos partidos, dos políticos tradicionais. Ele, como Trump, é o outsider, levado ao poder pelo eleitor despolitizado, novamente o grande ator. 
Os três exemplos revelam a profunda desorganização do sistema político que envolve a existência de um eleitorado não constituído como sujeito político, daí não formar uma coletividade política. Os partidos políticos nada representam e não se apresentam a partir de propostas ideologicamente consistentes. Tomando as possíveis consequências econômicas da saída da comunidade europeia para o Reino Unido, bem como das políticas econômicas e de cortes em áreas sociais propostas por Trump e Macron, quem perde é a grande massa dos eleitores pertencentes à classe média e à classe trabalhadora, principais responsáveis, eleitoralmente, pelas vitórias destes novos dirigentes.

Na América Latina, o caso do Brasil tem algumas similaridades com os exemplos anteriores, mas também características muito específicas.

O Brasil de 2017 é, na verdade, dois países distintos: um é composto de quase 210 milhões de pessoas que tratam de viver suas vidas e constituem a grande maioria de trabalhadores que lutam para manter o emprego ou estão desempregados. Esta população está completamente de costas para a vida política, despreza os partidos e os políticos e associa a crise econômica aos escândalos de corrupção. O outro Brasil é composto por alguns milhares de pessoas - entre esses, os políticos que estão no poder que buscam saídas para suas possíveis condenações por atos de corrupção, somados a uma elite burguesa industrial e financeira, preocupada exclusivamente com reformas neoliberais que garantam a precária reprodução do capitalismo do sul global. Em meio a estes dois grupos, aparece uma esquerda distribuída em poucos partidos, minoritária no legislativo nacional, que perdeu espaço eleitoral e tem pouca capacidade de mobilização, apoiada por grupos intelectualizados e centrais sindicais.

Este cenário foi gerado por uma prolongada crise política que teve seu nascedouro quando, pela primeira vez, após o regime cívico-militar, parte da população, ideologicamente postada no centro-direita e na direta do espectro político, organizou-se publicamente nas ruas para eleger um candidato à presidência da república. Isto não seria razão de crise, se o candidato derrotado não estimulasse a mobilização contra a Presidenta eleita, após o pleito. A partir daí, formou-se um caldo de cultura que passou a 
juntar uma massa nas ruas, os interesses da grande mídia e os setores financeiros e industriais, que viam no momento a grande oportunidade para desalojar do poder o Partido dos Trabalhadores, vencedor, pela $4^{\mathrm{a}}$ vez consecutiva, das eleições presidenciais. O que aconteceu de 2014 até 2017 foi a deslegitimação da política e dos partidos, o deslizamento do poder político do Legislativo e Executivo para o Judiciário, para o Ministério Público e para a Polícia Federal. É mister chamar a atenção para o fato de que a massa de eleitores de direita e centro-direita, que se mobilizou em manifestações pelo impeachment da presidenta, não se constituiu como novo sujeito político, não apoia o governo que colocou no poder, mas também não se manifesta contra.

A política, vista como centro do regime democrático, foi esfacelada, e as portas se abrem para referendos conservadores e para futuros candidatos à Presidência da República no estilo de Trump e Macron.

A dificuldade para reconstruir a política e o regime democrático é imensa. $O$ tempo e as formas que esta reconstrução tomará são impossíveis de prever, tanto no nível internacional como no Brasil. As previsões de vitórias democráticas beiram sempre o pensamento mágico, apontam mais para o desejo do que para possibilidades reais. De qualquer forma, um novo pacto democrático só se efetivará com uma nova relação entre o povo e a política, o que depende de uma nova configuração de ambos. A pósdemocracia aposta em um regime com instituições democráticas formais e com uma desmobilização política, que permita a este novo momento do capitalismo políticas de exclusão, de cortes de direitos sociais e de empobrecimento das camadas populares. 


\section{Bibliografia}

BALLESTRINI, Luciana. Imperialidade democrática como injustiça global: problemas para a democracia e a justiça no século XXI. In: MIGUEL, Luis Felipe; BIROLI, Flávia (orgs.) Encruzilhadas da Democracia. Porto Alegre: ZOUK, 2017.

BROWN, Wendy. Undoing the Demos. New York: Zone Books, 2016.

DADOT, Pierre; LAVAL Christian. A Nova Razão do Mundo: ensaio sobre a sociedade neoliberal. São Paulo: Boitempo,2016.

GRAMSCI, Antonio. Maquiavel e a Política e o Estado Moderno. Rio de Janeiro: Civilização Brasileira, 1978.

LACLAU, Ernesto. La Razón Populista. México: Fondo de Cultura, 2005.

MAQUIAVEL, Nicolau. O Princípe. São Paulo: Penguin Classics; Cia das Letras, 2010.

RANCIÈRE, Jacques. Dissensus on politics and aesthetics. London: Continuum. 2010. 